Decision-making in the arms of a dependent relationship: explaining shifts in importer acquisition patterns of major weapon systems, 1955-2007

Richard A.I. Johnson

Department of Politics, University of Strathclyde, Glasgow, United Kingdom

@_RichardJohnson

Corresponding Author:

Richard Johnson

4.17 McCance, 16 Richmond St, Glasgow, G1 1XQ, UK

+4401415482668

richard.johnson[at]strath.ac.uk

Acknowledgements: I would like to thank Scott Gartner, Caitlin Milazzo, Jeannette Money, Randy Siverson, Shaina Western, and an anonymous reviewer for their comments. All errors remain my own.

The author received no funding from any grant-awarding body.

The author has no conflicts of interests based on the direct applications of this research.

Replication data is available at www.richard-johnson.net 


\section{Decision-making in the arms of a dependent relationship: explaining shifts in importer acquisition patterns of major weapon systems, 1955-2007}

Arms dependency is typically framed as a security issue that states seek to avoid. Dependency creates an opportunity for an exporter to attempt to exert influence over the importer's foreign and domestic policy. However, the arms trade is a trade and influence attempts create economic costs for exporters by damaging relationships with current and potential customers. Thus, heavily dependent states do not necessarily need to change suppliers to avoid the threat. Additionally, as arms transfers are a signal of political support, dependency may be a sign of a mutually beneficial relationship rather than one that is potentially dangerous. This article evaluates these arguments using logistic regression models to evaluate changes in suppliers of major weapons systems. It finds that the relationship between dependence and arms transfers is more complex than previously argued where the nature of the relationship depends both on the type of exporter and the type of arm being exported.

Keywords: Arms transfers, arms importers, major weapon systems, dependency 
In the early 1960s, India found itself in a shifting security environment because they did not receive the F-104 fighters that the United States promised to sell to them. Concurrently, India's rivals were becoming larger threats. China was gaining power through its own domestic arms industries. Pakistan began receiving military aid from the United States - including the F-104 in 1962. The culmination of these semi-independent factors led India to change how they acquired fighter jets. It became a "matter of political "face" for New Delhi to take whatever steps were necessary to 'match' the Pakistani aircraft' (Graham 1964: 825). India's involvement in the nonaligned movement meant that they had more options to change suppliers compared to other states. One option was to open talks with the Soviet Union to import MIG 21s, while another option was to negotiate with the United Kingdom to import the BAC Lightning. In the end, India chose to import MIG 21s from the USSR - despite the jet being 2-3 years out of date in comparison to the BAC Lightning - because India wanted to assemble some of the aircraft domestically, which the United Kingdom would not allow (Graham 1964). India's long-term goal was to parlay the transferred assembly capabilities from the USSR into fighter aircraft that were Indian designed and produced.

Major weapon systems, such as fighter jets, are the primary tool for states to maintain security internally and externally. Despite the necessity of arms, relatively few states possess the capabilities to produce major weapon systems and must import arms at a significant cost (Buzan and Herring 1997; Johnson 2017; Levine et al. 1997). If the importer chooses to change suppliers, they must endure economic and security costs. First, the sunk costs of purchasing full weapon systems is lost and the cost of new weapon systems greatly increases over time, which means more economic resources are used (Bitzinger 1994; Garcia-Alonso 1999; Scheetz 2004). 
Second, arms deals typically include contracts for maintenance, spare parts, and ordnance over the expected lifetime of the arms, which further increases the sunk costs (Kemp 1979). Indeed, for arms manufacturers, the majority of their profit is provided by these contracts. Changing suppliers for a similar type of weapon system leads to additional contracts and, therefore, additional financial burdens. Third, states face an adjustment cost from having to train on new weapon systems as training often takes months (Harkavy 1987; Maoz 2006). In a time of crisis, having to retrain on new weapon systems can result in immediate losses on the battlefield.

Using an opportunity and willingness framework to enable theory development, I present two countering arguments on dependency and change. The security argument is arms dependence is a threat for importers as the supplier may withhold transfers of weapon systems, spare parts, or ordnance (Bitzinger 1994; Catrina 1988; Markusen 2004; Wheelock 1978). The economic argument is the structure of the arms market reduces any dependence threat because it is a buyer's market. Exporters need the economic benefits from export (Kinsella 2002; Pearson 1994) and exerting influence may have economic consequences.

The countering arguments on dependence highlights an issue in the arms trade literature: while the motives to transfer are known to be security and economic interests (most recently Akerman and Seim 2014; Comola 2012), the relative importance of these interests is generally unknown. This article increases the understanding of how security and economic interests drive the arms trade. 
To test the countering arguments on changing arms suppliers I use logit models. I examine the impact of dependency on hegemons, P5 suppliers that are not hegemons, and industrial suppliers on the likelihood of change. I find that when dependency is statistically significant and has a substantive effect it is consistently negative. Increased dependence leads to remaining at the status quo. These effects are strongest for hegemonic suppliers.

The role of dependence in arms transfer decision-making is under-appreciated and must continue to play a role in future research as government leaders often cite exerting influence as a benefit of weapon sales. One contribution of this article is a better understanding of the demand side of the arms trade. The decisions to change can affect the exporter's arms industries, particularly since the end of the Cold War. Exporters should be inclined to understand what conditions lead to customers shifting from the status quo. Another contribution is the result that security threats largely have no statistical impact on change, which implies that importers are confident in their suppliers.

\section{Changing arms acquisition}

While extensive literature examines the supply and demand motivations for arms transfers (e.g. Blanton 1999, 2005; Erickson 2011, 2015; Johnson and Willardson 2018; Kinsella 1994, 2002; Moore 2012; Platte and Leuffen 2016), the decision to change suppliers is often overlooked. The decision to produce arms is studied (e.g. Brauer 1991; Brzoska 1999; Buzan and Herring 1997; Kinsella 2000; Yesilyurt et al. 2013). Identifying why states change furthers our understanding 
of arms transfers beyond purely political and economic exchanges (e.g. Akerman and Seim 2014; Comola 2012).

The motivation to change suppliers is a balance of traditional security threats versus the security and economic costs that come from change. One way to organize the factors affecting the decision to change is to use an opportunity and willingness framework (e.g. Joyce, Ghosn, and Bayer 2014; Kinsella 2000; Most and Starr 1989). While many states have a willingness to change, not all states have the opportunity. Opportunity is a necessary condition for change and willingness is a sufficient condition. Thus, arms acquisition is more complex than other economic goods as security concerns create a constraint on the market.

\section{Opportunity}

The opportunity to change arms suppliers involves politics in the international system, characteristics of the arms market, and domestic economics. Depending on the status of these three factors, importers may not have the possibility to change.

During the Cold War, supply networks were dependent on the ideology of the importer, financial resources, and level of diplomatic isolation (i.e. the non-aligned movement) (Catrina 1988;

Mihalka 1979; Pearson 1994). Ideological limits on change shifted in the 1980s as competition from European suppliers and China grew, which increased in the post-Cold War system (Catrina 1988; Eikenberry 1995; Krause 1992). Ideological ties were no longer relevant, which meant the shift in polarity resulted in greater opportunity to change. 
Market shifts affected the opportunity to change over time due to decreasing defense budgets in producer states. Lower budgets, combined with increasing research and development costs, led to increased international cooperation on research and development and production (Bitzinger 1994). While research and development cooperation became more common in the post-Cold War period (Sköns and Wulf 1994), it was low enough to perpetuate market inefficiencies. Also, arms producers did not engage in comparative advantage with production (Brzoska 1999; Krause 1992); not even the post-Cold War European Union (Martin et al. 1999). The result was an increase in the economic push for export. As exporter defense budgets decrease, importer opportunities increase.

Domestic economic factors affect the opportunity for change because states must typically possess hard currency or credit to purchase arms. Historically, exporters face an economic push for export (Kinsella 2002; Pearson 1994). One exception was superpower military aid during the Cold War; states could even barter with the USSR (Frank 1969; Krause 1992). The need to pay is even stronger in the post-Cold War system (Keller and Nolan 1997; Schiff et al. 1998). Fewer economic resources reduce the importer's opportunity to change.

Lastly, change is limited by the substitutability of major weapon systems. When any good is produced by a handful of states, switching suppliers is difficult, particularly when the alternative suppliers were in the other bloc during the Cold War. The issue is two-fold. First, increasing research and design can lead to fewer producers, which reduces substitutability. Second, 
increasing complexity of the arms - such as training requirements for aircraft versus armored vehicles - reduces substitutability in the short-term due to training requirements.

\section{Willingness}

A state's willingness to change is based on the costs and benefits of change versus the status quo. I focus on the contradicting arguments underlying arms dependency's role in the decision to change. The political science literature considers dependency a security threat (e.g. Catrina 1988; Kinsella 1998); higher dependence may increase the willingness to change to avoid influence. Arms dependency also indicates an economic relationship between exporter and importer. In a historically buyer's market, exporters may not exert influence to keep customers; higher dependence may reduce the willingness to change. The threat - or lack thereof - of dependency also varies based on the type of supplier due to their different interests.

\section{Dependency}

Dependency occurs when three conditions are present. First, the major weapon system must be necessary for a core goal. 'Goals' may be wide ranging and include very different areas, such as security or prestige. Second, dependency becomes salient when there are not many alternative suppliers of identical or interoperable weapons. Third, weapon systems cannot be easily substitutable. Thus, the easier it is to switch suppliers, the less important it is to switch and viceversa. 
Dependency is affected by two factors - the importer's number of suppliers and the amount of arms imported from each supplier. As the number of suppliers increases, the dependence on any individual supplier decreases (Catrina 1988; Mihalka 1979). Additionally, as arms become more technologically complex and advanced, the potential supply network shrinks; dependence increases because fewer states are able to produce these more complex weapons (Catrina 1988; Krause 1992; Rosh 1990).

The issue is whether dependency is perceived as a threat that leads to change. The threat argument is dependency creates the possibility that exporters will exert influence over the importer's policies (Catrina 1988; Kinsella 1998; Krause 1991; Sislin 1994). The economic argument is the arms trade is a trade where closer ties negate any dependency threat due to exporter economic interests.

Arms imports pose an indirect/long-term security threat as importers become increasingly dependent on their supplier(s). The risk is the denial of delivery of full systems, spare parts, and/or ordnance during a time of national emergency, thereby impairing their ability to defend themselves fully (Blanton 1999; Markusen 2004; Wheelock 1978). ${ }^{1}$ Catrina (1988) examines the threat in-depth in his book and Kinsella (1998) finds that while arms imports into the Middle East makes importers more aggressive in two-thirds of states, increased arms dependency tempers aggression in just less than half of states. Being cut-off is a serious concern - all else equal - and if states desire to maximize their own security with lower dependency, the expected outcome is obvious: change suppliers. The security costs of dependency, however, are

\footnotetext{
${ }^{1}$ Due to data limitations, only the level of dependence on weapon systems can be tested. While transfers of spare parts and ordnance are important, data are not available.
} 
hypothetical. This cost is only paid if an unexpected or unaccounted for security threat arises and a supplier decides to exert influence.

An actual cost of dependency relates to economics - sunk costs. When weapons have been paid for, but not delivered, importers are particularly vulnerable to influence. A primary issue is the importer may not have enough resources to import additional weapons. Additionally, arms sales contracts often include provisions requiring the importer to purchase maintenance plans from the supplier that greatly increase the sunk costs (Kemp 1979). Even with military aid, sunk costs have occurred with training and logistics. New weapons would require another round of training and the spare parts and ordnance for different models of weapon systems must get to the correct unit.

The other argument is dependency is not a threat for importers, which comes from the economics literature and indirectly from the political science literature. ${ }^{2}$ Dependency is not a threat due to the structure of the market. Increasing research and design costs (Bitzinger 1994; Scheetz 2004) and the unwillingness to seek comparative advantage in production (Brzoska 1999; Krause 1992; Martin et al. 1999) means that arms producing states must export. As exporters increase production runs their learning curves are reduced (Brauer 2004; Brzoska 1999; Garcia-Alonso 1999; Keller and Nolan 1997), which increases economic benefits. Furthermore, states often cite balance of payment benefits as a motive for export (Eikenberry 1995; Keller and Nolan 1997; Krause 1992). Yet, the literature shows that balance of payment benefits do not occur (e.g.

\footnotetext{
${ }^{2}$ I thank an anonymous reviewer for highlighting this argument.
} 
Hartley 2000; Stanley and Pearton 1972). The perceived benefit is enough of an economic reason for suppliers to pursue export.

Similarly, but on the importer side, arms transfers occur under WTO rules that allow trade offsets to be included in the deal (Brauer and Dunne 2004). One common type of offset with arms is countertrade where the exporter agrees to arrange the purchase of goods produced in the importer equal to, or less than, the arms' value (Markowski and Hall 2004). At higher levels of competition there are more offsets (Catrina 1988), lowering the dependence threat.

The economic arguments indicate that exporters have many motivations to transfer arms. The result is an increasingly competitive arms market with exporters seeking to maximize their share. Exerting influence over the importer may have negative knock-on effects with future trade, both with importers and other potential customers witnessing the action.

\section{Evaluating the role of dependency across supplier type}

All else equal, the economic arguments are more convincing than the security arguments because the security threat faced is potential and the economic costs of change are calculable. For exporters, the economic structure of the market is public information and the potential costs for an exporter exerting influence can be measured. However, this argument implicitly assumes all exporters have similar interests, which is not true. Supplier interests vary. 
The Stockholm International Peace Research Institute (SIPRI) (1975) classified exporters as hegemonic, industrial, and restrictive. These classifications have evolved into examining exporters based on their interests related to security, influence, and economics (e.g. Krause 1991; Smith, Humm, and Fontanel 1985; Stohl and Grillot 2009). I consider suppliers as influence driven (hegemonic), security driven (P5 Security Council members that are not hegemons), and economic driven (industrial suppliers). ${ }^{3}$ To derive the hypotheses, I evaluate the motives of each supplier type to exert influence versus their economic interests.

The primary motivation for industrial suppliers is economic; their desire is to maintain, if not increase, market share. The motive to attempt influence over the importer is minimal due to economic interests, except under extreme condition. One extreme condition espoused by democratic suppliers is human rights, yet importer human rights violations are constantly shown to have a minimal, if any, effect on export decisions (e.g. Blanton 2005; Erickson 2011). Even Germany, an industrial supplier with domestic and constitutional law restricting arms exports (Johnson and Willardson 2018), transfer arms to human rights violators (Platte and Leuffen 2016). The dependency threat importers face from industrial suppliers is low, if not nonexistent.

The economic issue is an industrial supplier seeking to exert influence may result in the loss of a customer. More importantly, the negative reputation effects from exerting influence may lead to other customers seeking different suppliers (Smith, Humm, and Fontanel 1985) or potential customers going elsewhere. If dependence on industrial suppliers is not a threat, even when

\footnotetext{
${ }^{3}$ The motives I assign are the primary motive, not sole motive, of the supplier type.
} 
violating human rights, the importer has little reason change suppliers. However, dependency on an industrial supplier does not create indirect benefits as it does with other types of suppliers; thus, as the costs of change decrease as weapons become older, there is not a clear motivation to stick with their previous suppliers. Importers can seek the best deal on the market with industrial suppliers. Empirically, these arguments suggest a null relationship.

Hypothesis 1: Higher dependency on industrial suppliers does not have an effect on change.

P5 suppliers - UK, France, post-Cold War Russia, and China - have both economic and security interests. Influence motivations are comparatively less salient for these states. These suppliers are just as reliant on exports for economic viability as industrial suppliers (Catrina 1988; Krause 1992; Skons and Wulf 1994), but also have extensive security interests beyond their region. While P5 suppliers are powerful states, their power projection capabilities have decreased generally over time while China maintained regional capabilities. In turn, these suppliers become involved in fewer conflicts directly and often use arms exports as a foreign policy tool. The goal being to maintain their international security interests.

The importance of both economic and security interests indicates that dependency on P5 suppliers is not a threat for multiple reasons. First, the economic motivations to not exert influence match industrial suppliers: except under extreme conditions, the potential costs outweigh the benefit. Second, the extreme condition for influence would relate to the exporter's international security interests. However, there is a difference between supporting states in conflict versus trying to influence a state to initiate a conflict. A prime directive of P5 suppliers 
(technically) is promoting stability and reducing conflict in the system, which often manifests as providing support in the name of peace. P5 suppliers should support their security interests with willing partners, reducing the need for influence. As influence is not a threat, dependency will reduce the likelihood of change. ${ }^{4}$

Hypothesis 2: Higher dependency on P5 suppliers reduces the likelihood of change.

Hegemonic suppliers - the US and USSR - are motivated primarily to seek influence.

Economics matter, but to a much lesser extent compared to the other suppliers. Security interests also drive hegemonic action, but they have power projection capabilities to support their goals. The question is: does hegemonic interest in exerting influence to achieve security goals pose a security threat to importers?

If the security arguments on dependency are correct, dependency on a hegemonic supplier is a threat as they are seeking influence. Importers should seek to minimize the threat by adding additional suppliers. However, as with P5 suppliers, trying to exert influence to take offensive action is politically sensitive, unless those actions are domestic; hegemonic suppliers often provided arms for use in civil conflict/war.

Dependent relationships with a hegemon also create political and economic benefits. Politically, arms transfers are viewed as signs of foreign policy support (Catrina 1988; Kinsella and Tillema

\footnotetext{
${ }^{4}$ As these producers rarely get the opportunity to use their goods in true international conflict (obviously a good thing) there are also economic motives to not exert influence to restrict importers - displaying battlefield competency of the goods, particularly by a comparatively less trained military, helps increase reputation of the good.
} 
1995; Pierre 1981; Phythian 2000). The de-facto support is known by its neighbors, which may prevent aggressive actions. Alternatively, the goal of the transfer may be to reinforce a stable regional balance of power. Both situations create a lower international security threat for the importer. When an importer has fewer international security threats, the potential negatives of a dependent relationship are less important.

Economically, hegemons have a need to export (Krause 1992; Skons and Wulf 1994), but they also provide a large amount of military aid. States with the resources necessary to purchase arms from hegemons also have the resources to change suppliers, which reduces the dependency threat. States receiving military aid have a lower motivation to change as it would require increased defense spending, which means their decision is based on the actual economic cost of change versus the potential security threat of dependence. The combination of security, political, and economic factors indicates that dependency on a hegemonic supplier has clear benefits and calculable costs whereas influence being exerted is potential; thus, dependency is acceptable.

Hypothesis 3: Higher dependency on hegemonic suppliers reduces the likelihood of change.

Hypotheses 2 and 3 have the same expectation for P5 and hegemonic suppliers. Separation is necessary as potential differences in the magnitude of the effect of dependency provide information on the role of economics and security in the decision to change. If the dependency effect is larger with P5 suppliers versus hegemonic suppliers, the implication is importers view their economic power in the market as limiting the dependency threat. If the dependency effect 
is larger with hegemonic suppliers over P5 suppliers, the implication is that importers have greater confidence that their security importance to hegemons reduces any dependency threat.

\section{Traditional security streats}

The costs and benefits of dependency, along with the costs of changing suppliers, shift when an importer is facing traditional security threats. The threat may be external or internal. In addition, threats may be actual or perceived. For example, if a state and a rival are competing in an arms race without actual conflict the threat is lower than a current interstate war. Additionally, importers can reduce the necessity of change by stockpiling arms, allowing the state to survive a short-term crisis without resupply. Longer conflicts, though, inevitably require arms imports as stockpiles will eventually diminish (Brzoska and Pearson 1994; Kolodziej 1979; Krause 1992; Pearson 1989).

Interstate conflict is an immediate external threat. Conflict is unsustainable without resupply and it often determines the outcome of a conflict (Brzoska and Pearson 1994; Catrina 1988; Harkavy 1982; Kemp 1979). Thus, during interstate conflict - particularly war - importers have their backs against a wall and a lower willingness to change. The issue is the amount of time and training it takes for the operators to become adequate - let alone skilled - on the operation of a particular weapon systems useful for interstate conflict. $^{5}$

\footnotetext{
${ }^{5}$ For example, during the War of Attrition, the USSR agreed to provide Egypt with SA-3 surface-to-air missiles, but this complicated weapon system required six months of training for the operating team to become independent of their training staff (Maoz 2006). If the Russian advisers had not remained during the war to help Egyptian troops use the weapon system, the outcome may have been even worse for Egypt.
} 
Internal threats stem from organized opposition groups and rebel groups the state wants to control or defeat - regardless of the normative implications. To handle internal threats, states desire arms capable of efficiently controlling (or repressing) their population. These arms do not need to be high-tech, which means they are substitutable. When arms are substitutable with lower training start-up costs - such as armored vehicles - exporters have an economic motive to provide the weapon systems. The implication is that importers do not have to change suppliers.

Hypothesis 4: Greater security threats reduce the likelihood of change.

\section{Data and operationalization}

I examine the changing of arms suppliers between 1955 and 2007. The arms transfer data comes from SIPRI's Arms Trade Register database (SIPRI 2010). While SIPRI data identifies the importer, exporter, and model of transferred weapon system, it does not state who the original producer of the arms are - I gather this data on all available models from Jane's Defence online databases and historical handbooks. The sample of importers excludes states that produce the category of interest - all other states are included. I use a monadic unit of analysis because arms transfers are rare events; thus, using an exporter-importer dyadic sample would greatly increase the $\mathrm{N}$ without adding variation in the non-zero observations.

As not all arms are equal, I separate out the types of major weapon systems transferred based on their role in providing security similar to SIPRI's classifications along with Johnson (2017). I use the SIPRI land sub-categories of towed gun and self-propelled guns from the artillery 
category and separate tanks and armored personnel carriers from the armored vehicle category. ${ }^{6}$ From the SIPRI aircraft category, fighter/FGA planes, support planes, transport planes, support helicopters, and transport helicopters are separated for the tests. Thus, nine tests are conducted.

\section{Dependent variable}

The dependent variable is binary in all of the tests. It is coded as ' 1 ' if the importer changes supplier compared to their previous import - ' 0 ' otherwise. Change includes adding an additional supplier in the same category. As the unit of analysis is the importer-year and arms imports are a rare event, the median value of the dependent variable is zero.

\section{Independent variables}

The main independent variable is the level of arms dependence. I calculate dependence in a similar manner as Catrina (1988) and Kinsella (1998), but use the number of units as opposed to value. I take the number of units ordered from each state and divide it by the total number of units in each category to provide a measure ranging between 0 and 1 . The closer the dependence measure is to one, the more dependent the importer is on the supplier.

Arms imports by category are rare events compared to overall arms imports. This fact means that years can pass between transfers; therefore, the relevance of dependence decreases over time. To account for time and dependence I employ an exponential decay function on the

\footnotetext{
${ }^{6}$ Ship based systems are excluded from the analysis.
} 
dependence level at time of transfer until next transfer; thus, dependence decreases over time in the models.

Additionally, I separate out the type of supplier the importer may be dependent on - hegemonic, P5, or industrial. Hegemonic suppliers are the United States and Soviet Union. Major power suppliers are France, United Kingdom, China, and Russia. Industrial suppliers are the rest. The type of supplier is historically argued to make a difference in arms transfer decision-making (e.g. SIPRI 1975). I take the maximum dependence level in each category per year.

Hostility level - as a measure of short-term external threat - comes from the Correlates of War Militarized Interstate Dispute data and collected through EUGene (Ghosn, Palmer, and Bremer 2004; Bennet and Stam 2000). This measure is coded traditionally as zero through five, with '0’ the presence of no hostility and ' 5 ' the presence of an interstate war. Due to interstate conflicts rarely beginning out of nowhere, I use the maximum hostility level for the importer during each year. $^{7}$

As a measure of internal threat, I use the presence of civil conflict within a state. The data for this measure is from UCDP/PRIO Armed Conflict Dataset (Gleditsch et al. 2002). This variable is categorical with a range of zero to two. Zero means there is no civil conflict, ' 1 ' indicates there

\footnotetext{
${ }^{7}$ A long-term external threat measure is an importer's strategic reference group (SRG) (Maoz 2009). This measure is the ratio of the importer's capability level with capability level of the importer's enemies and the enemies' allies. Data from the ATOP alliance data set (Leeds et al. 2002), Thompson's (2001) rivalry data, and the Correlates of War CINC scores are used to create this measure. However, these data have a limited date range until 2000 and the coefficients in the tests are consistently insignificant; thus, I do not include the variable in the models in order to extend the date range through 2007 . These models are in the online appendix.
} 
are greater than 25 battle deaths a year due to civil conflict, and '2' indicates there are more than 1000 battle deaths due to civil conflict in a year. ${ }^{8}$

\section{Controls}

Alternatives to changing supplier exist for states facing security threats. The primary alternative is to form and maintain alliances - particularly defense pacts - with other states as a way of gaining security. Allies can provide direct support with soldiers to help reduce the threat the importing state faces if conflict occurs. One counter-argument is that states with larger alliance networks can reduce military spending that would allow for massive spending in the short-term if conflict occurs.

I create an additive sum of the capabilities of the importer's defense pact partners has during each year. I acknowledge this does not take into account the alliance members identity directly. ${ }^{9}$ The data to create the variable comes from the ATOP dataset (Leeds et al. 2002) and the Correlates of War Composite Index of National Capability (CINC) (Singer, Bremer, Stuckey 1972; Singer 1987). The CINC data is also used for the importer capability measure, which is the proportion of power a state possesses. As arms producers are not included in the importer sample, these values are extremely small; hence the large coefficients. ${ }^{10}$

\footnotetext{
${ }^{8}$ This measure may seem extreme, but there are few data sets on civil conflict that cover pre-1980.

${ }^{9}$ Alternatively, in a monadic research design a measurement of number of defense pact partners has been used before as a proxy for capability (e.g. Siverson and Johnson 2016), which does not account for capabilities.

${ }^{10}$ Models without importer capability are presented in the online appendix.
} 
Despite the desire importers may have to change due to a dependence threat, not all states have the opportunity to do so. In order to acquire arms - and shift from the status quo - importers need the financial means to do so. A higher GDP per capita allows a state access to economic resources for defense, which means change is possible. At minimum, the importer can afford to purchase arms from a different exporter at a high cost, if they fear dependence. The data for the GDP per capita of the importing state comes from Gleditsch (2002) and is logged. GDP per capita is used instead of GDP due to correlation issues between GDP and other variables.

During the Cold War most major and minor powers were clients of one of the two superpowers the US and the USSR - which meant most states were restricted to change within their sphere of influence. This means that during the Cold War importers should be less likely to change their suppliers due to lower opportunity. One exception, however, are states that belonged to the nonaligned movement. For example, India purchased arms from both the UK and the USSR without penalties from either superpower (Graham 1964). Thus, members of the non-aligned movement have more opportunity for change during the Cold War. For the members of the non-aligned movement, I assign a value of ' 1 ' if the importer is a member.

I also control for the number of years since last import. While time plays a role in the dependency measures, time since last import is important in order to account for the natural cycle of procurement. There are no correlation issues between this measure of time and the dependency measures. 
To account for substitutability, I control for the number of producers of each type of major weapon systems. This variable is composed using Jane's Defence publications online and in hard copy to determine who produced the models in SIPRI's arms trade register. The number of producers is logged because switching from one to two producers is significantly different from shifting from sixteen to seventeen.

Lastly, I include a five-year moving average of all arms imports to account for importer stockpiles/demand for weapons. This variable is created using SIPRI's trend-indicator value of the capabilities of major weapon systems. The moving average is why the tests being in 1955, as opposed to 1950.

\section{Test and results}

To test my arguments, I use binomial logits as the dependent variable is coded as $0 / 1$. A value of ' 1 ' represents that a change in supplier occurred compared to the previous import, which includes adding additional suppliers for the same weapon type. The standard errors are clustered by importer. Examination of correlation coefficients across the dependent variable, independent variables, and controls shows there are no multicollinearity issues. ${ }^{11}$ One test is present for each sub-category of major system: towed artillery, self-propelled artillery, armored personnel carriers, tank, fighter/fighter ground-attack aircraft, support plane, transport plane, support helicopter, transport helicopter.

\footnotetext{
${ }^{11}$ Tests using fixed effects are presented in the online appendix, as are tables with correlation matrices and summary statistics.
} 
[Table 1 near here]

A summary of the effects of dependency on change for the eighteen models are in Table 1; the full tables are presented in the appendix. I first discuss the statistical significance of the dependency variable coefficients and make comparisons across the models. Then I visually examine the substantive significance of the dependency coefficients. I finish with a discussion on the traditional security threat coefficients and substantive significance.

Table 1 identifies the direction of the statistically significant coefficients on the likelihood of change - empty cells indicate statistical insignificance. The significant dependency coefficients are all negative except three - P5 dependency for self-propelled guns during the Cold War, industrial dependency for APC during Cold War, and industrial dependency for support aircraft in the post-Cold War period. In only one test - towed guns in the Cold War - are all three types of dependency significant. Towed guns are highly substitutable with lower comparative training time, which means less need to change. This also applies to the P5 and industrial dependency coefficients in the towed gun post-Cold War model. The other models with two significant dependency coefficients are both in the Cold War: hegemon and P5 fighter aircraft and hegemon and industrial transport helicopter. The fighter aircraft results are as expected, including the stronger effect for hegemonic dependency versus P5 dependency. The difference for transport helicopter is hegemon models are often armed whereas industrial supplier models are not. The former is less substitutable during the Cold War leading to lower change probability where industrial models are more substitutable. The other tests have one statistically significant dependency coefficient. No coefficients are significant for post-Cold War self-propelled guns, 
support planes in both periods, and Cold War support helicopters. Thus, the general interpretation of the statistical significance of dependency is that when it matters - about $31 \%$ of coefficients - it reduces the likelihood of change with the three exceptions; overall, $41 \%$ of dependency coefficients support the hypotheses (including no significance on the industrial supplier coefficients).

The broader implication of only $41 \%$ of coefficients supporting the hypotheses is that the models do not perform particularly well. However, the poor performance actually informs on the role of dependency in arms transfer decision-making: it appears to just not be that important. This idea is further supported by only three coefficients having a positive significant coefficient against expectations. Thus, while the role of dependency in the arms trade has historically played a role in theory and empirics on importer action (e.g. Catrina 1988) and conflict processes (e.g. Kinsella 1998); its overall statistical effect on importer decisions is mixed at best. Instead of considering the effects independently, looking at the shifts across periods may highlight outcomes that are more interesting.

For towed guns and tanks in the post-Cold War models, hegemonic dependency becomes insignificant, as does P5 dependency for self-propelled guns and industrial dependency for APCs. These shifts in the statistical significance of dependency after the end of the Cold War suggest that importers no longer saw dependency as a benefit with hegemonic suppliers. There was also a larger range of suppliers to choose from and fewer security threats, which means importers could focus on their own interests separate from the hegemon. The only shift from insignificant in the Cold War to significant post-Cold War is with APCs. Dependency on the US 
in the post-Cold War for APCs may lead to a lower probability of change due lower international security interests increasing the export push in the US and importers facing civil unrest would find APCs useful for domestic security.

More changes occur in the aircraft models across periods. With hegemonic dependency, changes from significant to insignificant occur with transport aircraft and transport helicopters. P5 dependency changes occur with fighter aircraft from significant to insignificant and support helicopters from insignificant to significant. Industrial dependency changes with transport helicopters from significant to insignificant.

These changes relate to the shifts in the market with former Soviet states possessing large stockpiles and a lower need for weapons. Russia became a P5 supplier and the number of industrial suppliers increased with former satellite state independence. As the Soviet Union produced a large amount of transport aircraft and helicopters, the lack of dependency being significant in the post-Cold War is unsurprising. The continued significance of fighter aircraft, however, highlights the importance placed on jet fighter aircraft by importers, which provides the possessor with prestige even if not needed for a security threat (Suchman and Eyre 1992).

While Table 1 illustrates the effects of dependency, it does not account for the substantive effect of the full models. In other words, what effect does dependency have when other variables are accounted for? To establish if the statistically significant coefficients have a substantive effect, I examine visually the marginal effect of dependency on the probability of an importer changing suppliers with other variables held at their mean. 
Figures 1 and 2 present the marginal effects for dependency. I only present graphs with statistically significant negative coefficients as the three positive coefficients have no substantive effect. A full set of figures is in the online appendix. The $\mathrm{x}$-axis is the range of dependency. The $\mathrm{y}$-axis is the probability of change. I note the $\mathrm{y}$-axis scale differs across figures. The probability of change is never too high in the point prediction because, as stated earlier, arms imports are comparatively rare events. ${ }^{12}$

[Figure 1 near here]

Figure 1 is land weapons. During the Cold War, as dependency on all suppliers increases for towed guns, the probability of change decreases. The largest effect is for hegemons, followed by industrial and then P5 suppliers. The overall negative trend, though, is similar - a shift in a probability of change from about 0.03 to virtually zero. In the post-Cold War model, a substantive effect is only present for P5 and industrial suppliers; though the shift is only from about 0.0175 to near zero. For APCs in the post-Cold War period and tanks with hegemon suppliers in the Cold War period, the negative effect of dependency is similar to towed guns, but the confidence intervals are wider and the slopes are less steep. Additionally, the point estimates for change are higher for APC and tanks -0.06 and 0.08 to just under 0.02 , respectively.

[Figure 2 near here]

\footnotetext{
${ }^{12}$ No graphs are presented for self-propelled guns and support helicopters as the different types of dependency have no substantive effect on the probability of change.
} 
Figure 2 is marginal effects of dependency in the aircraft models. Six of the eight graphs are for dependency on hegemonic suppliers. The only graph of note is Cold War hegemonic dependency for fighter aircraft, which has a clear negative slope with narrow confidence intervals as dependency increases. The other graphs have slight substantive significance, but the width of the confidence intervals highlight that significance is only present when comparing the lowest levels of dependency versus the maximum. This result holds with the two nonhegemonic supplier graphs too.

[Figure 3 near here]

Across both figures, there is one consistent finding: as dependency on a supplier increases, the substantive effect is a negative shift on the probability of change. However, significance is only present when comparing the lowest and highest levels of dependency - otherwise the confidence intervals cross. The exceptions are Cold War dependency on towed guns and hegemonic dependency for fighter aircraft. The former being among the lowest technology weapons with the highest number of suppliers. The latter being among the highest technology weapons with the fewest suppliers in the Cold War. Both scenarios create a motivation to stay at the status quo.

Lastly, Hypothesis 4 - traditional security threats decrease the likelihood of change - is not supported with most coefficients. When the coefficients are statistically significant - six instances of $36(17 \%)$ - only three are substantively significant. These are international conflict for APC and tank and for civil conflict with transport helicopters during the Cold War. 
However, the effect for the land weapons graphs is only barely present. What is interesting is the shift in the probability of change with transport helicopters. During civil war, importers have a $30 \%$ chance of changing their supplier; twice as high as when there is no civil conflict/war. The combined uniqueness of transport helicopters from looking at dependency and ongoing conflict may stem from the role transport helicopters play in civil conflict. Compared to planes, helicopters need less infrastructure to operate. Thus, they provide the ability to transport people and material into remote locations without an airport, which helps a state's internal power projection; in most civil conflicts, the threat to shooting down a helicopter is minimal.

\section{Conclusion}

This article examines the role of dependency on the decision to change arms suppliers. Dependency is important to consider as the political science literature historically argues it is a potential threat to importers (e.g. Blanton 1999; Bitzinger 2004; Catrina 1988; Kinsella 1998; Krause 1991; Sislin 1994); however, these arguments do not always account for the role of economics in importer choice and exporter decision to exert influence. While a large portion of coefficients are insignificant, I find that as states face higher levels of dependence on hegemonic suppliers they are more likely to stay at the status quo. Shifts in dependency on P5 or industrial suppliers, however, have substantive effects that are extremely small. The culmination of the findings indicate, at a minimum, that importers do not consider dependency on their arms suppliers as a security threat. At a maximum, dependency barely factors into an importer's arms acquisition decisions. One implication is that exporter state assertions - especially democracies that dependency leads to the ability to influence importers is greatly weakened. If democracies 
cannot exert influence over importers, then justifications for transferring the human rights violators is also weakened. Alternatively, an implication of my research is that arms suppliers should not worry about importers taking action to reduce dependency by changing suppliers, which provides more stability to the suppliers. The lack of a dependency threat implies that importers are willing to continue relationships due to benefits from linkages with a supplier or economic benefits from stability.

For conflict, surprisingly, the only real shift in change occurring is for transport helicopters during the Cold War. This result - or lack thereof - is most likely due to the costs that are involved with changing arms suppliers during conflict. Concurrently, long-term security is statistically insignificant as well and omitted from the presented models in order to increase the time range of the tests. The explanation for this result is long-term security is a potential cost while the economic cost of change is immediately quantifiable.

Overall, understanding arms importer behavior provides knowledge on how the major suppliers should act in order to maintain stable status quo relationships. As the number of arms diffusing throughout the international system increases, states will have an increasing number of tools to disrupt peace internally and externally. Thus, this article is an important step in investigating the demand side of arms transfer decision-making and changes in their patterns. An area for future research would be to consider the role dependence plays in importer's domestic and foreign policy actions. 
Table 1. Summary of direction of significant dependency coefficients for all models

\begin{tabular}{|c|c|c|c|c|c|}
\hline & $\begin{array}{l}\text { Hegemonic } \\
\text { Dependency }\end{array}$ & $\begin{array}{c}\text { P5 } \\
\text { Dependency }\end{array}$ & $\begin{array}{c}\text { Industrial } \\
\text { Dependency }\end{array}$ & $\begin{array}{c}\text { International } \\
\text { Conflict }\end{array}$ & $\begin{array}{c}\text { Civil } \\
\text { Conflict }\end{array}$ \\
\hline Towed Gun, Cold War & - & - & - & + & \\
\hline Towed Gun, Post-Cold War & & - & - & & \\
\hline Self-Propelled Gun, Cold War & & + & & & \\
\hline \multicolumn{6}{|l|}{ Self-Propelled Gun, Post-Cold War } \\
\hline APC, Cold War & & & + & + & + \\
\hline APC, Post-Cold War & - & & & & \\
\hline Tank, Cold War & - & & & & \\
\hline \multicolumn{6}{|l|}{ Tank, Post-Cold War } \\
\hline Fighter Aircraft, Cold War & - & - & & & \\
\hline Fighter Aircraft, Post-Cold War & - & & & & \\
\hline \multicolumn{6}{|l|}{ Support Aircraft, Cold War } \\
\hline Support Aircraft, Post-Cold War & & & + & & \\
\hline Transport Aircraft, Cold War & - & & & & \\
\hline \multicolumn{6}{|l|}{ Transport Aircraft, Post-Cold War } \\
\hline \multicolumn{6}{|l|}{ Support Helicopter, Cold War } \\
\hline Support Helicopter, Post-Cold War & & - & & & \\
\hline Transport Helicopter, Cold War & - & & - & + & + \\
\hline Transport Helicopter, Post-Cold War & & & & & + \\
\hline
\end{tabular}


Figure 1. Marginal effect of dependency with other variables held at mean and $95 \%$ confidence intervals - land weapons

Figure 2. Marginal effect of dependency with other variables held at mean and $95 \%$ confidence intervals - aircraft

Figure 3. Marginal effect of dependency with other variables held at mean and $95 \%$ confidence intervals - conflict 


\section{Appendix}

Table A1. Binomial logit results for likelihood of change - land weapons, Cold War

\begin{tabular}{lcccc} 
& Towed Gun & Self-Propelled Gun & APC & Tank \\
\hline \hline Dependency on Hegemonic Supplier & $-12.98^{* *}$ & 0.84 & -1.29 & $-2.93^{*}$ \\
& $(3.35)$ & $(1.87)$ & $(1.11)$ & $(1.32)$ \\
Dependency on P5 Supplier & $-5.68^{* *}$ & $9.58^{* *}$ & -1.36 & 0.03 \\
& $(1.85)$ & $(3.45)$ & $(2.55)$ & $(1.67)$ \\
Dependency on Industrial Supplier & $-8.43^{* *}$ & -6.37 & $5.12^{*}$ & 4.68 \\
& $(2.29)$ & $(6.02)$ & $(1.99)$ & $(3.76)$ \\
Importer Capabilities & $-34.47^{* *}$ & -23.59 & $-37.42^{* *}$ & $-41.34^{*}$ \\
& $(11.12)$ & $(14.26)$ & $(12.21)$ & $(18.24)$ \\
Sum of Alliance Capabilities & $-1.79^{*}$ & -0.16 & -0.50 & $-1.97^{* *}$ \\
& $(0.82)$ & $(1.17)$ & $(0.61)$ & $(0.62)$ \\
Importer Hostility Level & $0.15^{* *}$ & 0.08 & $0.11^{* *}$ & $0.15^{* *}$ \\
& $(0.05)$ & $(0.08)$ & $(0.03)$ & $(0.03)$ \\
Importer Civil Conflict & 0.29 & -0.00 & 0.11 & 0.09 \\
Importer GDP/pc (Log) & $(0.16)$ & $(0.28)$ & $(0.16)$ & $(0.13)$ \\
& $-0.39^{* *}$ & $0.40^{* *}$ & 0.01 & -0.10 \\
Non-Aligned & $(0.14)$ & $(0.13)$ & $(0.09)$ & $(0.09)$ \\
Years Since Last Import & 0.03 & -0.29 & $0.47^{*}$ & 0.06 \\
Number of Producers (Log) & $(0.31)$ & $(0.45)$ & $(0.24)$ & $(0.20)$ \\
Arms Imports Moving Average (Log) & -0.01 & -0.02 & $0.04^{* *}$ & $0.03^{* *}$ \\
Constant & $(0.01)$ & $(0.01)$ & $(0.01)$ & $(0.01)$ \\
N & 0.31 & 0.64 & 0.05 & $-1.28^{* *}$ \\
\hline \hline
\end{tabular}

Std. Errors Clustered by Importer

$* \mathrm{p}<0.05 * * \mathrm{p}<0.01$ 
Table A2. Binomial logit results for likelihood of change - land weapons, post-Cold War

\begin{tabular}{lcccc} 
& Towed Gun & Self-Propelled Gun & APC & Tank \\
\hline \hline Dependency on Hegemonic Supplier & -54.99 & -2.41 & $-3.51^{*}$ & 0.95 \\
& $(57.79)$ & $(4.07)$ & $(1.72)$ & $(1.79)$ \\
Dependency on P5 Supplier & $-15.08^{*}$ & 0.33 & -4.19 & 1.60 \\
& $(6.27)$ & $(5.83)$ & $(3.30)$ & $(2.60)$ \\
Dependency on Industrial Supplier & $-10.56^{*}$ & 0.15 & 0.57 & 2.71 \\
Importer Capabilities & $(4.32)$ & $(4.61)$ & $(2.11)$ & $(3.08)$ \\
& 13.87 & $-85.55^{*}$ & -23.76 & -33.59 \\
Sum of Alliance Capabilities & $(27.37)$ & $(34.21)$ & $(17.15)$ & $(26.35)$ \\
& -0.71 & -0.15 & 0.49 & 1.12 \\
Importer Hostility Level & $(2.38)$ & $(1.59)$ & $(0.71)$ & $(0.76)$ \\
Importer Civil Conflict & 0.20 & 0.14 & 0.08 & -0.05 \\
& $(0.11)$ & $(0.09)$ & $(0.05)$ & $(0.07)$ \\
Importer GDP/pc (Log) & 0.25 & -0.16 & 0.33 & 0.00 \\
& $(0.26)$ & $(0.34)$ & $(0.17)$ & $(0.28)$ \\
Years Since Last Import & -0.35 & -0.02 & $0.30^{* *}$ & -0.13 \\
Number of Producers (Log) & $(0.20)$ & $(0.26)$ & $(0.11)$ & $(0.14)$ \\
Arms Imports Moving Average (Log) & -0.03 & -0.02 & -0.01 & -0.02 \\
Constant & $(0.02)$ & $(0.01)$ & $(0.01)$ & $(0.01)$ \\
N & 0.50 & 2.70 & $2.70^{* *}$ & 0.27 \\
\hline \hline
\end{tabular}

Std. Errors Clustered by Importer

$* \mathrm{p}<0.05 * * \mathrm{p}<0.01$ 
Table A3. Binomial logit results for likelihood of change - aircraft, Cold War

\begin{tabular}{lccccc} 
& Fighter & Support & Transport & Support & Transport \\
& Aircraft & Aircraft & Aircraft & $\begin{array}{c}\text { Helicopter } \\
\text { Helicopter }\end{array}$ \\
\hline \hline Dependency on Hegemonic Supplier & $-6.47^{* *}$ & 1.56 & $-2.46^{* *}$ & 3.05 & $-1.95^{*}$ \\
& $(0.96)$ & $(1.98)$ & $(0.79)$ & $(2.28)$ & $(0.76)$ \\
Dependency on P5 Supplier & $-2.43^{*}$ & 3.05 & 0.05 & 4.69 & -0.81 \\
& $(1.18)$ & $(3.01)$ & $(1.44)$ & $(2.64)$ & $(0.91)$ \\
Dependency on Industrial Supplier & -1.06 & & 2.19 & -3.37 & $-3.20^{*}$ \\
& $(2.99)$ & & $(1.75)$ & $(12.91)$ & $(1.44)$ \\
Importer Capabilities & -21.35 & $25.80^{* *}$ & 1.36 & 12.19 & -1.10 \\
& $(14.77)$ & $(6.63)$ & $(5.35)$ & $(12.03)$ & $(5.31)$ \\
Sum of Alliance Capabilities & 0.06 & -1.05 & -0.97 & -1.33 & -0.65 \\
& $(0.56)$ & $(1.16)$ & $(0.61)$ & $(1.19)$ & $(0.57)$ \\
Importer Hostility Level & 0.06 & -0.06 & 0.03 & 0.03 & $0.08^{* *}$ \\
Importer Civil Conflict & $(0.03)$ & $(0.06)$ & $(0.03)$ & $(0.07)$ & $(0.03)$ \\
& 0.02 & 0.42 & 0.20 & -0.18 & $0.44^{* *}$ \\
Importer GDP/pc (Log) & $(0.12)$ & $(0.22)$ & $(0.11)$ & $(0.27)$ & $(0.12)$ \\
& -0.10 & $0.38^{*}$ & -0.12 & 0.28 & 0.16 \\
Non-Aligned & $(0.10)$ & $(0.16)$ & $(0.11)$ & $(0.19)$ & $(0.09)$ \\
Years Since Last Import & 0.13 & $-0.82^{* *}$ & 0.03 & $-0.87^{*}$ & -0.09 \\
Number of Producers (Log) & $(0.19)$ & $(0.32)$ & $(0.20)$ & $(0.39)$ & $(0.18)$ \\
Arms Imports Moving Average (Log) & $0.04^{* *}$ & -0.02 & 0.01 & -0.02 & $0.04^{* *}$ \\
Constant & $(0.01)$ & $(0.01)$ & $(0.01)$ & $(0.01)$ & $(0.01)$ \\
N & $-1.75^{* *}$ & -0.30 & -0.27 & $2.50^{* *}$ & -0.44 \\
\hline \hline & $(0.34)$ & $(0.49)$ & $(0.29)$ & $(0.63)$ & $(0.27)$ \\
& $0.83^{* *}$ & $0.44^{* *}$ & $0.28^{* *}$ & $0.55^{* *}$ & $0.29^{* *}$ \\
& $(0.06)$ & $(0.08)$ & $(0.04)$ & $(0.11)$ & $(0.04)$ \\
& $-1.77^{* *}$ & $-5.58^{* *}$ & $-2.42 * *$ & $-12.27^{* *}$ & $-2.23^{* *}$ \\
& $(0.65)$ & $(0.93)$ & $(0.50)$ & $(1.67)$ & $(0.48)$ \\
& 4590 & 4590 & 4590 & 4590 & 4590 \\
\hline
\end{tabular}

Std. Errors Clustered by Importer

$* \mathrm{p}<0.05 * * \mathrm{p}<0.01$ 
Table A4. Binomial logit results for likelihood of change - aircraft, post-Cold War

\begin{tabular}{lccccc} 
& Fighter & Support & Transport & Support & Transport \\
& Aircraft & Aircraft & Aircraft & $\begin{array}{c}\text { Helicopter } \\
\text { Helicopter }\end{array}$ \\
\hline \hline Dependency on Hegemonic Supplier & $-5.69^{* *}$ & -14.73 & -4.14 & 3.95 & 0.97 \\
& $(1.37)$ & $(10.97)$ & $(2.43)$ & $(4.46)$ & $(1.11)$ \\
Dependency on P5 Supplier & -0.16 & 9.24 & 3.19 & $-103.94^{*}$ & -0.78 \\
& $(1.83)$ & $(5.33)$ & $(4.20)$ & $(50.18)$ & $(1.76)$ \\
Dependency on Industrial Supplier & 4.79 & $12.96^{* *}$ & 10.76 & & -3.96 \\
& $(2.44)$ & $(4.77)$ & $(7.72)$ & & $(3.49)$ \\
Importer Capabilities & -10.97 & $25.12^{*}$ & 11.39 & -15.46 & 4.41 \\
& $(14.95)$ & $(11.23)$ & $(11.58)$ & $(26.13)$ & $(13.11)$ \\
Sum of Alliance Capabilities & 0.76 & 1.83 & $2.55^{* *}$ & 2.16 & 1.56 \\
& $(1.20)$ & $(1.11)$ & $(0.92)$ & $(2.46)$ & $(0.82)$ \\
Importer Hostility Level & 0.11 & -0.15 & -0.13 & -0.15 & -0.08 \\
Importer Civil Conflict & $(0.06)$ & $(0.08)$ & $(0.08)$ & $(0.19)$ & $(0.05)$ \\
& 0.16 & 0.29 & 0.33 & -0.02 & $0.56^{* *}$ \\
Importer GDP/pc (Log) & $(0.19)$ & $(0.34)$ & $(0.29)$ & $(0.43)$ & $(0.20)$ \\
& $-0.36^{*}$ & 0.24 & -0.18 & 0.11 & -0.04 \\
Years Since Last Import & $(0.16)$ & $(0.26)$ & $(0.11)$ & $(0.48)$ & $(0.10)$ \\
Number of Producers (Log) & -0.02 & $-0.03^{*}$ & -0.01 & -0.03 & -0.01 \\
Arms Imports Moving Average (Log) & $(0.01)$ & $(0.01)$ & $(0.01)$ & $(0.02)$ & $(0.01)$ \\
Constant & 0.92 & -0.24 & 1.07 & $-3.41^{*}$ & $2.80^{* *}$ \\
N & $(1.01)$ & $(1.55)$ & $(0.99)$ & $(1.64)$ & $(0.67)$ \\
\hline \hline
\end{tabular}

Std. Errors Clustered by Importer

$* \mathrm{p}<0.05 * * \mathrm{p}<0.01$ 


\section{Works Cited}

Akerman, A. and A. L. Seim. 2014. "The Global Arms Trade Network 1950-2007.” Journal of Comparative Economics 42(3): 535-551.

Bennett, D. S., and A. Stam. 2000. "EUGene: A Conceptual Manual.” International Interactions 26: 179-204.

Bitzinger, R. A. 1994. "The globalization of the arms industry: The next proliferation challenge." International Security 19(2): 170-198.

Blanton, S. L. 1999. "Instruments of Security or Tools of Repression? Arms Imports and Human Rights Conditions in Developing Countries.” Journal of Peace Research 36(2): 233-244.

Blanton, S. L. 2005. "Foreign Policy in Transition? Human Rights, Democracy, and US Arms Exports.” International Studies Quarterly 49 (4): 647-668.

Brauer, J. 1991. “Arms Production in Developing Nations: The Relation to Industrial Structure, Industrial Diversification, and Human Capital Formation." Defence and Peace Economics 2(2): 165-175.

Brauer, J. 2004. "Economic Aspects of Arms Trade Offsets." In Arms Trade and Economic Development: Theory, Policy, and Cases in Arms Trade Offsets, edited by J. Brauer and P. Dunne. 54-65. New York: Routledge.

Brauer, J., and P. Dunne. 2004. Arms Trade and Economic Development: Theory, Policy, and Cases in Arms Trade Offsets. New York: Routledge.

Brzoska, M. 1999. “Economic Factors Shaping Arms Production in Less Industrialized Countries." Defence and Peace Economics 10(2): 139-169.

Brzoska, M. and F. S. Pearson. 1994. Arms and Warfare: Escalation, de-Escalation, and Negotiation. Columbia, SC: University of South Carolina Press. 
Buzan, B. and E. Herring. 1998. The Arms Dynamic in World Politics. Boulder, CO: Lynne Rienner Publishers.

Catrina, C. 1988. Arms Transfers and Dependence. New York: Taylor \& Francis.

Comola, M. 2012. "Democracies, Politics, and Arms Supply." Review of International Economics 20(1): 150-163.

Eikenberry, K. W. 1995. Explaining and Influencing Chinese Arms Transfers. Coillingdale, PA: DIANE Publishing.

Erickson, J. L. 2011. "Market Imperative Meets Normative Power: Human Rights and European Arms Transfer Policy.” European Journal of International Relations 19(2): 209-234.

Erickson, J. L. 2015. "Saint or Sinner? Human Rights and U.S. Support for the Arms Trade Treaty.” Political Science Quarterly 130(3): 449-474.

Frank, L. A. 1969. The arms trade in international relations. New York: Praeger Publishers.

Garcia-Alonso, M. C. 1999. "Price Competition in a Model of Arms Trade." Defence and Peace Economics 10(3): 273-303.

Ghosn, F., G. Palmer, and S. A. Bremer. 2004. “The MID3 Data Set, 1993-2001: Procedures, Coding Rules, and Description.” Conflict Management and Peace Science 21(2): 133154.

Gleditsch, N.P., P. Wallensteen, M. Eriksson, M. Sollenberg, and H. Strand. 2002. “Armed Conflict 1946-2001: A New Dataset.” Journal of Peace Research 39(5): 615-637.

Gleditsch, K. 2002. “Expanded Trade and GDP Data." Journal of Conflict Resolution 46(5): $176-214$

Graham, I. 1964. “The Indo-Soviet MIG Deal and Its International Repercussions.” Asian Survey 4(5): 823-832. 
Harkavy, R. E. 1982. Great power competition for overseas bases: the geopolitics of access diplomacy. New York: Pergamon Press.

Harkavy, R. E. 1987. “Arms Resupply During Conflict: A Framework for Analysis.” In The Economics of Military Expenditures, edited by C. Schmidt. 239-82. London: Macmillan Press.

Hartley, K. 2000. "The Benefits and Costs of the UK Arms Trade." Defence and Peace Economics 11(3): 445-459.

Johnson, R. A. I. 2017. “The Role and Capabilities of Major Weapon Systems Transferred between 1950 and 2010: Empirical Examinations of an Arms Transfer Data Set." Defence and Peace Economics 28(3): 272-97.

Johnson, R. A. I. and S. L. Willardson. 2018. "Human Rights and Democratic Arms Transfers: Rhetoric Versus Reality with Different Types of Major Weapon Systems.” International Studies Quarterly 62(2): 454-464.

Joyce, K. A., F. Ghosn, and R. Bayer. 2013. "When and Whom to Join: The Expansion of Ongoing Violent Interstate Conflicts." British Journal of Political Science 44(1): 205238.

Keller, W. W. and J. E. Nolan. 1997. “The Arms Trade: Business As Usual?” Foreign Policy, no. 109: 113-25.

Kemp, G. 1979. “Arms Transfers and the 'Back-End' Problem in Developing Countries.” In Arms Transfers in the Modern World, edited by S. Neuman and R. Harkavy. 264-275. New York: Praeger.

Kinsella, D. 1998. "Arms Transfer Dependence and Foreign Policy Conflict." Journal of Peace Research 35(1): 7-23. 
Kinsella, D. 1994. “Conflict in Context: Arms Transfers and Third World Rivalries During the Cold War." American Journal of Political Science 38 (3): 557-581.

Kinsella, D. “Arms Production in the Third Tier: An Analysis of Opportunity and Willingness." International Interactions 26 (3): 253-86.

Kinsella, D. 2002. "Rivalry, Reaction, and Weapons Proliferation: A Time-Series Analysis of Global Arms Transfers.” International Studies Quarterly 46 (2): 209-230.

Kinsella, D., and H. K. Tillema. 1995. "Arms and Aggression in the Middle East: Overt Military Interventions, 1948-1991." Journal of Conflict Resolution 39 (2): 306-329.

Kolodziej, E. A. 1979. “Arms Transfers and International Politics: The Interdependence of Independence." In Arms Transfers in the Modern World, edited by S. Neuman and R. Harkavy. 3-26 New York: Praeger.

Krause, K. 1992. Arms and the state: patterns of military production and trade. Cambridge: Cambridge University Press.

Krause, K. 1991. "Military Statecraft: Power and Influence in Soviet and American Arms Transfer Relationships.” International Studies Quarterly 35 (3): 313-336.

Leeds, B. A., J. M. Ritter, S. M. Mitchell, and A. G. Long. 2002. “Alliance Treaty Obligations and Provisions, 1815-1944." International Interactions 28(3): 237-260.

Levine, P., R. Smith, L. Reichlin, and P. Rey. 1997. “The Arms Trade.” Economic Policy 12(25): 335-70.

Maoz, Z. 2006. Defending the Holy Land: a critical analysis of Israel's security \& foreign policy. Ann Arbor: University of Michigan Press. 
Maoz, Z. 2009. "The Effects of Strategic and Economic Interdependence on International Conflict Across Levels of Analysis." American Journal of Political Science 53(1): 223240.

Markowski, S. and P. Hall. 2004. "Mandatory Defense Offsets - Conceptual Foundations." In Arms Trade and Economic Development: Theory, Policy, and Cases in Arms Trade Offsets, edited by J. Brauer and P. Dunne. 44-53. New York: Routledge.

Martin, S., K. Hartley, and A. Cox. 1999. "Defence Procurement of Dual-Use Goods: Is There a Single Market in the European Union?" Defence and Peace Economics 10 (1): 55-77.

Markusen, A. 2004. “Arms Trade as Illiberal Trade.” In Arms Trade and Economic Development: Theory, Policy, and Cases in Arms Trade Offsets, edited by J. Brauer and P. Dunne. 66-88. New York: Routledge.

Mihalka, M. 1979. "Supplier-Client Patterns in Arms Transfers: The Developing Countries, 1967-76." In Arms Transfers in the Modern World, edited by S. Neuman and R. Harkavy. 49-76. New York: Praeger.

Moore, M. 2012. "Selling to Both Sides: The Effects of Major Conventional Weapons Transfers on Civil War Severity and Duration." International Interactions 38(3): 325-347.

Most, B. A., and H. Starr. 1989. Inquiry, Logic, and International Politics. Columbia: University of South Carolina Press.

Pearson, F. S. 1989. “The Correlates of Arms Importation.” Journal of Peace Research 26(2): 153-163.

Pearson, F. S. 1994. The Global Spread of Arms: Political Economy of International Security. Oxford: Westview Press. 
Phythian, Mark. 2000. The Politics of British Arms Sales Since 1964: To Secure Our Rightful Share. Manchester, UK: Manchester University Press.

Pierre, Andrew J. 1982. The Global Politics of Arms Sales. New Jersey: Princeton University Press.

Platte, H. and D. Leuffen. 2016. "German Arms Exports: Between Normative Aspirations and Political Reality." German Politics 25(4): 561-580.

Rosh, R. M. 1990. "Third World Arms Production and the Evolving Interstate System.” The Journal of Conflict Resolution 34(1): 57-73.

Scheetz, T. 2004. “The Argentine Defense Industry: an Evaluation.” In Arms Trade and Economic Development: Theory, Policy, and Cases in Arms Trade Offsets, edited by J. Brauer and P. Dunne. 205-216. New York: Routledge,

Schiff, J., S. Gupta, and B. Clements. 1998. "Worldwide Military Spending, 1990-95.” Defence and Peace Economics 9(3): 237-281.

Sköns, E., and H. Wulf. 1994. "The Internationalization of the Arms Industry." Annals of the American Academy of Political and Social Science 535: 43-57.

Singer, J. D., S. Bremer, and J. Stuckey. 1972. “Capability Distribution, Uncertainty, and Major Power War, 1820-1965.” In Peace, War, and Numbers, edited by B. Russett. 19-48. Beverly Hills: Sage.

Singer, J. D. 1987. "Reconstructing the Correlates of War Dataset on Material Capabilities of States, 1816-1985" International Interactions 14(2): 115-32.

SIPRI. 1975. The Arms Trade with the Third World: Revised and Abridged Version. New York: Holmes and Meier.

SIPRI. 2010. “Arms Transfers Database.” 
Sislin, J. 1994. “Arms as Influence: The Determinants of Successful Influence.” Journal of Conflict Resolution 38(4): 665-689.

Siverson, R. M. and R. A. I. Johnson. 2016. "Trigger-happy? Military Regimes and the Timing of Conflict." Conflict Management and Peace Science Available online: https://doi.org/10.1177/0738894216673614

Smith, R., A. Humm, and J. Fontanel. 1985. "The Economics of Exporting Arms." Journal of Peace Research 22(3): 239-247.

Stanley, J., and M. Pearton. 1972. The International Trade in Arms. New York: Praeger.

Stohl, R. and S. Grillot. 2009. The International Arms Trade. Cambridge, UK: Polity Press.

Suchman, M. C. and D. P. Eyre. 1992. "Military Procurement as Rational Myth: Notes on the Social Construction of Weapons Proliferation.” Sociological Forum 7(1): 137-161.

Thompson, W. R. 2001. "Identifying Rivals and Rivalries in World Politics." International Studies Quarterly 45(4): 557-586.

Wheelock, T. R. 1978. “Arms for Israel: the limit of leverage.” International Security 3(2): 123137.

Yesilyurt, F., B. Güloğlu, E. Yesilyurt, and S. Sezgin. 2013. "The Determinants of Arms Production." Defence and Peace Economics 25(2): 205-211. 